\title{
E-MODUL BERBASIS CONTEXTUAL TEACHING AND LEARNING PADA MATERI SISTEM KOLOID UNTUK SMA/MA
}

\section{Mira Fatmawati ${ }^{*}$, Andromeda ${ }^{2}$}

1,2 Prodi Kimia, Universitas Negeri Padang, Padang, Indonesia

*Corresponding Author: mirafatma262@gmail.com

\section{ART I CLE I N F O}

Article history:

Received July 26, 2021

Revised July 30, 2021

Accepted September 17, 2021

Available online October 25, 2021

Kata Kunci:

Miskonsepsi, Kesetimbangan Kimia, Strategi PDEODE

Keywords:

Media Padlet, Phet Simulation

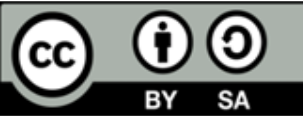

This is an open access article under the CC BY-SA license.

Copyright $(2021$ by Author. Published by Universitas Pendidikan Ganesha.

\begin{abstract}
A B S T R A K
Bahan ajar yang digunakan di sekolah masih berupa buku cetak. Selain buku cetak, guru juga pernah menggunakan modul dalam proses pembelajaran namun penggunaannya belum maksimal dikarenakan terbatas pada beberapa materi saja. Modul yang digunakan guru belum menampilkan karakteristik tertentu seperti penggunaan langkah pembelajaran kontekstual sehingga minat belajar peserta didik untuk mempelajari modul masih rendah. Penelitian ini bertujuan untuk menciptakan e-modul berbasis contextual teaching and learning pada materi system koloid untuk SMA/MA. Penelitian ini merupakan jenis penelitian pengembangan. Subjek penelitian ini yaitu 2 validator, 3 guru kimia dan peserta didik kelas XII. Metod epengumpulan data menggunakan wawancara dan angket. Instrumen penelitian berupa lembar wawancara peserta didik, angket uji validitas, dan angket praktikalitas. Teknik analisis data menggunakan analisis kuantitatif dan kualitatif. Hasil penelitian menunjukkan e-modul mempunyai nilai rata-rata validitas 0.90 dengan kategori valid, praktikalitas guru $95 \%$ dengan kategori sangat praktis, dan praktikalitas peserta didik $84 \%$ dengan kategori praktis. Maka, emodul berbasis contextual teaching and learning pada materi system koloid untuk SMA/MA sudah valid dan praktis. sehingga dapat digunakan pada proses pembelajaran. Implikasi penelitian ini diharapkan dapat membantu siswa dalam memahami materi system koloin. Sehingga dapat meningkatkan hasil belajar siswa.
\end{abstract}

\begin{abstract}
A B S T R A C T
The teaching materials used in schools are still in the form of printed books. In addition to printed books, teachers have also used modules in the learning process, but their use has not been maximized because they are limited to a few materials. The module used by the teacher has not displayed certain characteristics such as the use of contextual learning steps so that students' interest in learning to study the module is still low. This study aims to create an e-module based on contextual teaching and learning on colloidal system material for SMAMMA. This research is a type of development research. The subjects of this study were 2 validators, 3 chemistry teachers and class XII students. Methods of collecting data using interviews and questionnaires. The research instruments were student interview sheets, validity test questionnaires, and practicality questionnaires. The data analysis technique used quantitative and qualitative analysis. The results showed that the e-module has an average validity value of 0.90 with a valid category, 95\% teacher practicality in a very practical category, and $84 \%$ student practicality in a practical category. So, contextual teaching and learningbased e-modules on colloidal system materials for SMA/MA are valid and practical. so that it can be used in the learning process. The implications of this research are expected to help students in understanding the material of the koloin system. So that it can improve student learning outcomes.
\end{abstract}

\section{PENDAHULUAN}

Pada era revolusi 4.0, perkembangan teknologi yang begitu pesat dapat dijadikan sebagai peluang dalam mengembangkan bahan ajar elektronik seperti e-modul (Gevi \& Andromeda, 2019; Kodir et al., 2017; Miranda et al., 2021). Pada kondisi saat ini, adanya pandemi covid-19 membuat pembelajaran dialihkan dari pembelajaran tatap muka menjadi pembelajaran daring atau pembelajaran jarak jauh (W. A. 
F. Dewi, 2020; Media et al., 2021; Putria, 2020). Perkembangan penggunaan internet telah membantu pembelajaran jarak jauh menjadi lebih mudah dan cepat (Setiawan, 2020; R. M. Wijayanti \& Fauziah, 2020). Bahan ajar merupakan salah satu perangkat input yang harus ada dalam proses pembelajaran. Bahan ajar adalah pendekatan implementasi dari kurikulum yang berlaku (Gerhardt-Szép et al., 2017; Udy Nugroho et al., 2019; Zulkarnain et al., 2015). Kurikulum 2013 menuntut peserta didik agar dapat belajar secara aktif dan mandiri. Penggunaan teknologi dalam pembelajaran dapat meningkatkan capaian pembelajaran, efektivitas pengajaran, dan dapat mempengaruhi apa dan bagaimana seharusnya pembelajaran itu dipelajari dan dibelajarkan (Nugrahaeni et al., 2017; Nurkolis \& Muhdi, 2020). Penggunaan teknologi tidak hanya sekedar transfer pengetahuan tetapi harus memberikan kesempatan kepada peserta didik untuk memahami dan menguasai konsep dan prinsip melalui eksplorasi dan investigasi, pola, perubahan dan hubungan dengan berbantuan teknologi (Kulagina et al., 2021; Sudarmin \& Samini, 2016).

Namun kenyataannya, pelaksaan pembelajaran saat ini banyak mengalami kendala dalam pembelajaran kimia (Asmiyunda et al., 2018; Islamiati et al., 2020). Berdasarkan hasil wawancara dengan guru kimia di beberapa sekolah Kabupaten Solok, yaitu SMAN 1 Lembang Jaya, SMAN 2 Lembang Jaya, SMAN 1 Bukit Sundi, dan SMAN 1 Kubung menyatakan bahwa bahan ajar yang digunakan di sekolah masih berupa buku cetak. Selain buku cetak, guru juga pernah menggunakan modul dalam proses pembelajaran namun penggunaannya belum maksimal dikarenakan terbatas pada beberapa materi saja. Hal tersebut mengakibatkan kurangnya variasi bahan ajar. Modul yang digunakan guru belum menampilkan karakteristik tertentu seperti penggunaan langkah pembelajaran kontekstual sehingga minat belajar peserta didik untuk mempelajari modul masih rendah. Selain itu, berdasarkan hasil angket 40 orang peserta didik di beberapa sekolah Kabupaten Solok, yaitu masing-masing 10 orang peserta didik SMAN 1 Lembang Jaya, SMAN 2 Lembang Jaya, SMAN 1 Bukit Sundi, dan SMAN 1 Kubung mengungkapkan bahwa $82,5 \%$ peserta didik menyatakan bahwa buku kimia disekolah sulit dipahami. Kesulitan dalam memahami buku pelajaran mengakibatkan motivasi belajar peserta didik menjadi rendah. Hasil wawancara guru juga menyatakan bahwa peserta didik kurang berpartisipasi dalam proses pembelajaran. Berdasarkan hasil angket, sebanyak $97,5 \%$ peserta didik membutuhkan bahan ajar yang disusun dan disajikan dengan menarik serta memiliki kaitan materi dengan kehidupan nyata. Bahan ajar yang dimaksud adalah e-modul dan sebanyak $85 \%$ peserta didik memerlukan e-modul untuk menunjang pembelajaran. jika permasalahan tersebut dibiarkan akan memberikan dampak buruk terhadap hasil belajar siswa.

Solusi yang dapat dilakukan yaitu dengan menggunakan bahan ajar yang sesuai dengan karakteristik siswa serta menerapkan berbagai model pembelajaran. Pembelajaran kontekstual dapat mendorong guru untuk memotivasi peserta didik dalam menghubungkan pengetahuan dan aplikasinya dengan kehidupan nyata sehingga mereka aktif dalam proses belajar (Antara \& Aditya, 2019; Zulaiha, 2016). Pada e-modul dapat diterapkan suatu model pembelajaran yang sesuai dengan tuntutan kurikulum 2013(Gevi \& Andromeda, 2019). Salah satu model pembelajaran yang sesuai dengan kurikulum 2013 adalah model pembelajaran contextual teaching and learning. Model pembelajaran contextual teaching and learning merupakan suatu rancangan pembelajaran yang melibatkan pengamalam peserta didik dalam kehidupan nyata dengan materi pelajaran (Handini et al., 2016; Sailer et al., 2021; Sulfemi, 2019). Selain itu, model pembelajaran contextual teaching and learning dapat menambah pemahaman konsep (P. yulia A. Dewi \& Primayana, 2019; Yulkifli et al., 2020; Zulaiha, 2016). CTL mempunyai pengaruh positif terhadap motivasi belajar peserta didik dalam pembelajaran IPA(Rahmawati, 2018). Pengaruh positif tersebut terlihat pada saat guru memberikan soal-soal latihan dan peserta didik sangat berpartisipasi dalam mengerjakannya. Partisipasi peserta didik meningkat karena adanya kegiatan mengaitkan materi pelajaran dengan konteks lingkungan hidup peserta didik (Ratnasari \& Saefudin, 2018; Wildani et al., 2021). Model CTL dapat memberikan pengalaman nyata bagi peserta didik sehingga peserta didik menjadi tahu dan paham dengan makna pembelajaran (Sedana et al., 2013; Wildani et al., 2021; Zulaiha, 2016). Materi sistem koloid merupakan salah satu materi kimia yang diajarkan di kelas XI SMA/MA. Materi sistem koloid bersifat kontekstual dan memiliki banyak contoh dikehidupan sehari-hari (Ranny, 2019). Model pembelajaran contextual teaching and learning dapat dimanfaatkan untuk mempelajari materi ini, karena model ini menghubungkan materi pelajaran dengan penerapan dikehidupan nyata (Yusnindar, 2015).

Temuan penelitian sebelumnya menunjukkan bahwa e-modul yang dikembangkan sudah layak dan praktis (Asmiyunda et al., 2018; Ernica, 2019). Selain itu, temuan lain menyatakan bahwa e-modul fisika yang dikembangkan menggunakan model pembelajaran CTL sudah valid dan praktis serta dapat menumbuhkan literasi sains siswa (Nurhasnah \& Sari, 2020). E-modul yang dikembangkan menggunakan pendekatan contextual teaching and learning sudah valid, praktis dan efektif digunakan dalam proses pembelajaran (Yulkifli et al., 2020). E-modul disusun berpedoman kepada buku Kemendikbud (2017), 
Depdiknas (2008) dan Suryosubroto (1983). E-modul dikembangkan menggunakan komponen pembelajaran CTL. Komponen CTL terdiri dari 5 yaitu, relating, experiencing, applying, cooperating, dan, transfering. Pembelajaran kontekstual cocok diterapkan pada materi sistem koloid karena materi tersebut memiliki banyak contoh dan penerapan dikehidupan sehari-hari. Adapun tujuan dari penelitian ini adalah untuk menciptakan e-modul berbasis contextual teaching and learning pada materi sistem koloid yang valid dan praktis.

\section{METODE}

Jenis penelitian yang digunakan adalah penelitian dan pengembangan atau Research and Development (R\&D). Metode R\&D digunakan untuk membuat suatu produk kemudian diuji keefektifannya. Penelitian ini akan dilakukan tahun pelajaran 2021/2022 di FMIPA UNP dan SMAN 2 Lembang Jaya. Subjek penelitian ini yaitu validator dan peserta didik kelas XII SMAN 2 Lembang Jaya. Validator terdiri dari dua orang dosen kimia FMIPA UNP dan tiga orang guru kimia. Penelitian ini menggunakan model pengembangan Plomp yang terbagi atas 3 langkah, yaitu penelitian pendahuluan (preliminary research), pembentukan prototipe (prototyping stage), dan penilaian (assessment phase). Tahap pendahuluan, pada tahap ini dilakukan analisis kebutuhan, tinjauan literatur dan analisis konsep. Tahap analisis kebutuhan bertujuan untuk mengumpulkan informasi tentang permasalahan bahan ajar disekolah. Pada tahap ini, dilakukan proses wawancara bersama guru kimia dan pengisian angket oleh peserta didik. Tinjauan Literatur, pada tahap ini kegiatan yang dilakukan yaitu mencari informasi yang berguna untuk mendukung proses penelitian dari buku, artikel, jurnal, dan sumber lainnya. Analisis Konsep, pada tahap ini dilakukan identifikasi, analisis, dan penyusunan konsep-konsep dari materi sistem koloid. Hasil dari analisis tersebut dapat dibuat dalam bentuk tabel analisis konsep. Tahap Pembentukan Prototipe, berdasarkan data yang diperoleh pada tahap pendahuluan, maka dapat disusun suatu rancangan emodul berbasis contextual teaching and learning pada materi sistem koloid. Pada tahap ini dihasilkan empat prototipe. Setiap prototipe yang dihasilkan akan dilakukan evaluasi formatif. Evaluasi formatif tersebut dapat dikelompokkan menjadi beberapa bagian terdapat pada Gambar 1.

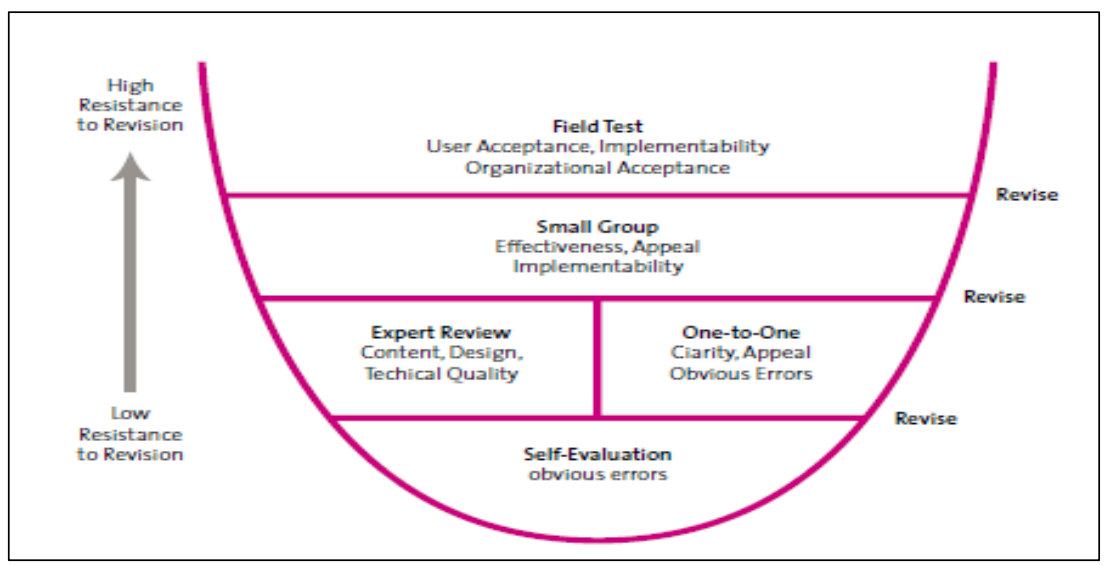

Gambar 1. Evaluasi formatif (Plomp, 2007).

Tahap pembentukan prototipe dilakukan beberapa kegiatan prototipe I disusun dan dirancang dalam bentuk e-modul berbasis contextual teaching and learning. E-modul dirancang sesuai dengan tuntutan KD 3.14 pada mata pelajaran kimia kurikulum 2013 kelas XI SMA/MA. E-modul disusun menggunakan komponen pembelajaran contextual teaching and learning yang terdiri dari 5 komponen yaitu relating, experiencing, applying, cooperating dan transfering. Dalam e-modul terdapat pertanyaan penggiring untuk menemukan konsep materi dan di bagian akhir e-modul disediakan lembar evaluasi sebagai alat ukur sejauh mana peserta didik memahami materi pelajaran. Prototipe II, pada tahap ini dilakukan evaluasi formatif berupa evaluasi diri sendiri. Kegiatan evaluasi diri sendiri dilakukan dengan cara sistem checklist terhadap bagian-bagian penting dalam e-modul. Jika masih terdapat bagian yang kurang, maka dilakukan revisi sehingga dihasilkan prototipe II. Prototipe III, pada tahap ini dilakukan penilaian terhadap e-modul yang dikembangkan. Penilaian tersebut meliputi penilaian ahli (expert review) dan uji coba satu satu (one to one evaluation) untuk mendapatkan validitas dari e-modul yang dikembangkan.

Penilaian dilakukan oleh validator yaitu dosen kimia dan guru kimia. Instrumen penilaian yang digunakan berupa lembar angket validitas. Angket uji validitas berisi beberapa pertanyaan terkait aspek 
kelayakan isi, penyajian, kebahasaan dan kegrafisan. Validator akan memberikan penilaian terhadap masing-masing pertanyaan yang diberikan. Lembar angket ini akan dianalisis setelah validator memberikan penilaian terhadap e-modul yang sedang dikembangkan. Penilaian validator untuk angket validitas ini berupa skor terhadap aspek yang dinilai dan disesuaikan dengan kriteria yang terdapat pada skala Likert yang dimodifikasi dari (Riduwan \& Sunarto, 2007), yaitu 4 (sangat setuju), 3 (setuju), 2 (tidak setuju), dan 1 (sangat tidak setuju). Angket dianalisis menggunakan formula Aiken's $V . V$ (koefisien validitas), lo (angka penilaian validitas yang terendah), c (angka penilaian validitas yang tertinggi), $r$ (skor kategori pilihan validator), dan $n$ (banyak validator). Menurut (Retnawati, 2016) jika nilai $v \leq 0,4$ maka validitasnya kurang, jika nilai besar 0,4 dan $\leq 0,8$ maka validitasnya sedang, dan jika nilai v besar dari 0.8 maka validitasnya tinggi. Tahap uji coba satu dilakukan bersama tiga orang peserta didik melalui proses wawancara. Peserta didik yang akan diwawancara direkomendasikan oleh guru berdasarkan kemampuan yang berbeda-beda yaitu, tinggi, sedang, dan rendah. Kemudian dilakukan penilaian dan tindak lanjut dari hasil wawancara terhadap produk yang sedang dikembangkan.

Prototipe IV, pada Prototipe IV dilakukan kegiatan uji coba kelompok kecil terhadap Prototipe III yang sudah valid. Uji coba kelompok kecil dilakukan terhadap 15 orang peserta didik dan 3 orang guru kimia melalui angket praktikalitas. Pemilihan peserta didik sama dengan pemilihan peserta didik pada uji coba satu satu. Analisis angket uji praktikalitas dilakukan dengan menggunakan rumus persentase kepraktisan. Dengan kriteria kepraktisannya yaitu 86\% - 100\% (sangat praktis), 76\% - 85\% (praktis), 60\% - 75 (cukup praktis), 55\% - 59\% (kurang praktis), dan $\leq 54 \%$ (tidak praktis) (Purwanto, 2009). Tahapan penilaian dilakukan untuk menyimpulkan apakah e-modul yang dikembangkan dapat digunakan di lapangan. Tahap penilaian terdiri atas praktikalitas dan efektivitas. Pada tahap ini dilakukan praktikalitas dan efektifitas terhadap kelompok kecil kemudian dilakukan uji lapangan (field test). Pada penelitian ini dibatasi sampai tahap penilaian yaitu praktikalitas e-modul dalam kelompok kecil. Penilaian dilakukan oleh guru dan peserta didik. Jika terdapat perbaikan maka dilakukan revisi sesuai dengan saran-saran yang diberikan. Revisi dilakukan untuk meningkatkan kualitas produk. Rancangan dan prosedur penelitian model Plomp secara keseluruhan terdapat pada Gambar 2.

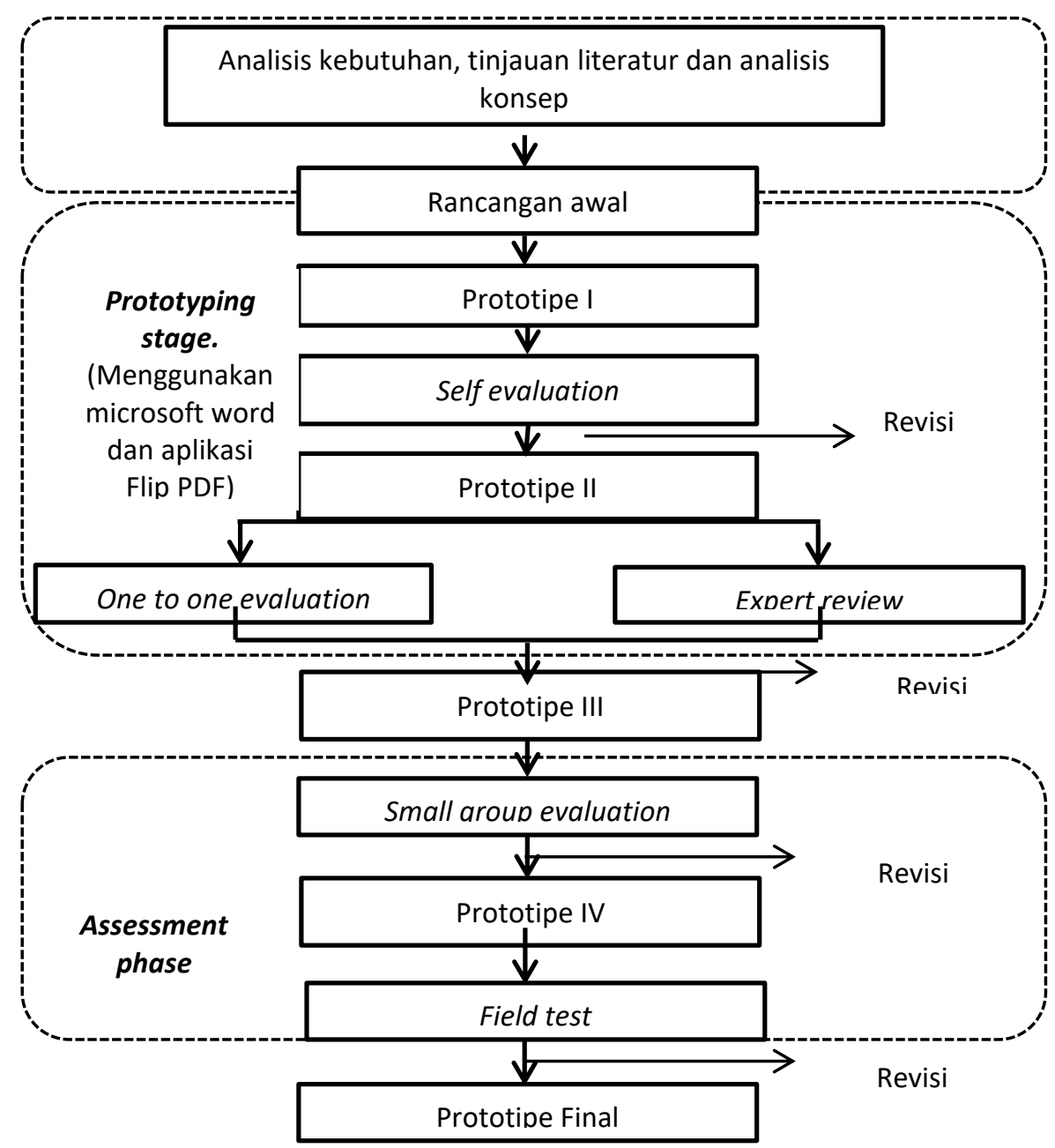

Gambar 2. Prosedur model pengembangan Plomp 


\section{HASIL DAN PEMBAHASAN}

Hasil

Hasil penelitian ini adalah sebuah produk e-modul berbasis contextual teaching and learning pada materi sistem koloid yang dikembangkan menggunakan model pengembangan Plomp. Model pengembangan Plomp dipandang lebih luwes dan fleksibel dibandingkan 4-D dikarenakan pada setiap langkahnya memuat kegiatan pengembangan yang disesuaikan dengan karakteristik penelitiannya. Model pengembangan ini menggunakan pendekatan prototipe, dimana untuk memperoleh produk yang berkualitas pendekatan prototipe dipilih sebagai pendekatan yang sesuai. Dalam penelitian dan pengembangannya melibatkan partisipasi guru dan peserta didik dengan menggunakan prosedur interaktif untuk menghasilkan prototipe pembelajaran (Rochmad, 2012). Model pengembangan Plomp terdiri dari 3 tahapan yaitu penelitian pendahuluan (preliminary research), pembentukan prototipe (prototyping stage), dan penilaian (assessment phase). Penjelasan dan hasil dari ketiga tahapan pengembangan dapat diuraikan sebagai berikut:

Pertama, penelitian Pendahuluan. Pada tahap ini dilakukan analisis kebutuhan, tinjauan literatur, dan analisis konsep. Kegiatan analisis kebutuhan bertujuan untuk mencari informasi terkait bahan ajar yang digunakan di sekolah. Kegiatan dimulai dengan melakukan wawancara bersama 4 orang guru kimia di SMAN Kabupaten Solok yaitu SMAN 1 Lembang Jaya, SMAN 2 Lembang Jaya, SMAN 1 Bukit Sundi, dan SMAN 1 Kubung. kemudian dilakukan pengisian angket oleh 40 orang peserta didik di sekolah yang sama dengan masing-masing 10 orang per sekolah. Lembar wawancara dan lembar angket berisikan pertanyaan seputar bahan ajar yang digunakan dalam pembelajaran. Hasil wawancara kepada guru didapatkan informasi terkait bahan ajar antara lain bahan ajar yang digunakan guru masih berupa buku cetak, guru pernah menggunakan bahan ajar modul, namun penggunaannya belum maksimal dikarenakan terbatas pada beberapa materi saja, modul yang digunakan tersebut belum menampilkan karakteristik tertentu seperti penggunaan langkah pembelajaran kontekstual, guru memiliki ketertarikan untuk menggunakan e-modul dalam proses pembelajaran karena dapat menambah pengalaman belajar peserta didik. Hasil angket kepada peserta didik didapatkan informasi antara lain peserta didik menyatakan bahwa bahan ajar yang dimilikinya hanya berupa buku cetak, peserta didik menyatakan bahwa buku cetak yang dimiliki masih sulit dipahami, peserta didik membutuhkan bahan ajar yang memiliki kaitan materi dengan kehidupan nyata, sebagian besar peserta didik belum pernah belajar menggunakan emodul, peserta didik membutuhkan suatu bahan ajar dengan inovasi baru seperti e-modul. Berdasarkan hasil analisi kebutuhan maka dikembangkanlah suatu e-modul berbasis contextual teaching and leaning. Tahap analisis konsep telah dilakukan dengan cara menganalisis konsep-konsep yang terdapat pada materi sistem koloid. Materi sistem koloid dalam kurikulum 2013 revisi 2018 diajarkan pada kelas XI semester genap. Konsep materi sistem koloid di analisis dari KD. 3.14. mengelompokkan berbagai tipe sistem koloid, dan menjelaskan kegunaan koloid berdasarkan sifat-sifatnya. Materinya meliputi konsep koloid, jenis-jenis koloid, sifat koloid, koloid liofil dan liofob, cara pembuatan koloid, dan kegunaan koloid.

Kedua, pembentukan Prototipe. Pada tahap ini dihasilkan empat prototipe. Setiap prototipe yang dihasilkan dilakukan evaluasi formatif. Evaluasi formatif bertujuan untuk menyempurkan e-modul yang dikembangkan. E-modul dapat dikembangkan untuk meningkatkan minat belajar dari peserta didik (Solikin, 2018). Kegiatan pertama yaitu pembentukan prototipe I. Prototipe I berupa e-modul berbasis CTL pada materi sistem koloid. Komponen e-modul disusun berpedoman kepada "Panduan Praktis Penyususnan E-Modul" oleh Kemendikbud dan "Sistem Pengajaran dengan Modul" oleh Suryosubroto. Pada tahap ini disajikan suatu gambar. Gambar yang disajikan berupa contoh-contoh fenomena dalam kehidupan. Melalui tahapan relating ini diharapkan dapat membantu peserta didik dalam menghubungkan pengetahuan yang sudah ada pada mereka dengan pengetahuan baru yang berkaitan dengan materi pelajaran. Komponen kedua yaitu experiencing. Experiencing adalah tahap peserta didik mengalami sendiri proses pembelajaran. Pada tahap ini disajikan suatu video atau gambar. Peserta didik melakukan pengamatan terhadap video atau gambar yang diberikan. Melalui pengamatan tersebut, peserta didik mengalami sendiri proses pembelajaran. Komponen ketiga yaitu applying, yang berarti menerapkan konsep yang sudah didapatkan dalam proses pembelajaran. Peserta didik dapat menerapkan konsep ketika terlibat dalam pemecahan masalah. Pada tahap ini, diberikan suatu lembar kerja yang terdiri dari beberapa pertanyaan. Peserta didik menjawab pertanyaan-pertanyaan sesuatu dengan konsep yang sudah diperolehnya pada tahap relating dan experiencing. Dalam menyelesaikan lembar kerja, peserta didik dapat bertukar dan berbagi informasi dengan peserta didik lainnya ataupun guru melalui tahap cooperating (bekerja sama). Penyelesaian masalah ketika belajar dalam kelompok lebih baik dibandingkan dengan belajar sendiri.

Komponen terakhir dari pembelajaran CTL yaitu transfering. Transfering merupakan kegiatan mentransfer atau memindahkan pengetahuan yang sudah diperoleh dalam konteks yang baru. Pada tahap ini disajikan suatu lembar evaluasi berupa soal-soal objektif yang berkaitan dengan materi sistem koloid. 
Peserta didik diharapkan mampu menyelesaikan semua soal dengan baik. Kegiatan transfering ini dapat dijadikan sebagai salah satu alat ukur untuk mengetahui sejauh mana peserta didik mengetahui pembelajaran. E-modul dibuat menggunakan Microsoft word 2010 dan aplikasi Flip Pdf. Jenis huruf yang digunakan berupa times new roman dan arial black dengan ukuran huruf disesuaikan. Desain tampilan emodul memiliki warna dominasi orange dan warna-warna lainnya sebagai pelengkap dan untuk memperindah tampilan. Setelah dihasilkan prototipe I, maka dilakukan evaluasi formatif berupa evalusi diri sendiri. Kegiatan evaluasi diri sendiri dilakukan untuk melihat dan mengoreksi bagian-bagian atau komponen dari e-modul. Berdasarkan lembar angket self evaluation, semua komponen e-modul yang dirumuskan sudah terdapat dalam e-modul sehingga tidak perlu dilakukan revisi. Setelah dihasilkan prototipe II, selanjutnya dilakukan evaluasi formatif berupa penilaian ahli dan uji coba satu satu.

Penilaian ahli berupa validasi dari e-modul. E-modul divalidasi menggunakan angket uji validitas. Uji validitas dimaksudkan untuk mengetahui apakah e-modul yang dibuat sudah sesuai dengan kebutuhan peserta didik secara efektif dan efisien. Kegiatan validasi produk dilakukan oleh beberapa pakar atau tenaga ahli yang sudah berpengalaman untuk menilai kelemahan dan kekuatan dari produk yang dihasilkan. E-modul divalidasi oleh lima orang validator yang ahli dalam bidang kimia diantaranya terdiri dari dua orang dosen kimia dan tiga orang guru kimia. Terdapat empat komponen validitas yang dinilai oleh validator, meliputi komponen isi, komponen penyajian, komponen kebahasaan, dan komponen kegrafisan (Depdiknas, 2008). Hasil data yang didapatkan dianalisis menggunakan rumus Aiken`s V. Grafik hasil uji validitas dapat dilihat pada Gambar 3.

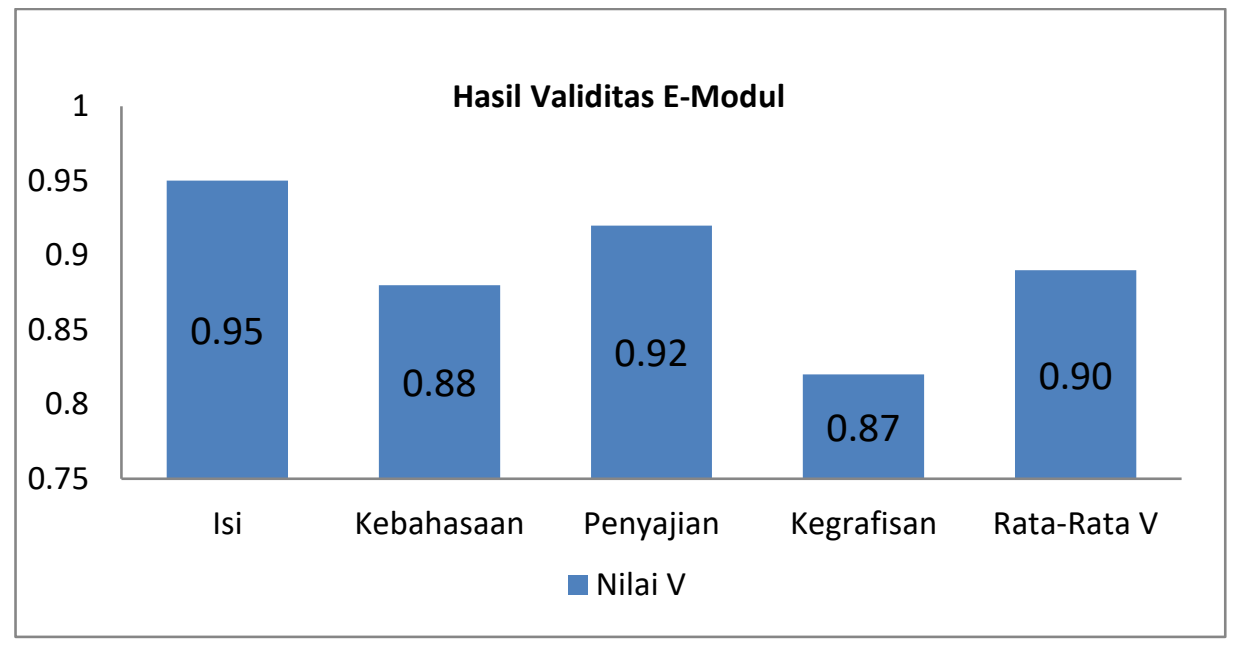

Gambar 3. Grafik nilai validitas e-modul.

Penilaian komponen isi adalah penilaian terhadap produk yang dikembangkan berdasarkan kurikulum yang relevan. Berdasarkan hasil pengolahan data, menunjukkan bahwa e-modul dari segi kelayakan komponen isi sudah valid dengan nilai $\mathrm{V}=0.95$. Penilaian komponen kebahasaan adalah penilaian yang dilakukan terhadap bahasa yang digunakan dalam e-modul. Berdasarkan hasil pengolahan data komponen kebahasaan dari e-modul dinyatakan valid dengan nilai $\mathrm{V}=0.88$. Pada indikator penggunaan kaidah Bahasa Indonesia yang baik nilai belum valid dengan nilai $\mathrm{V}=0.8$. Berdasarkan hal tersebut, validator menyarankan untuk memperbaiki ejaan bahasanya. Oleh karena itu, dilakukan beberapa perbaikan meliputi memperbaiki kata-kata yang salah, memperbaiki penggunaan huruf kapital dan mengganti kata hubung yang kurang tepat. Berdasarkan hasil pengolahan data, komponen kegrafisan dari e-modul dinyatakan valid dengan nilai $\mathrm{V}=0.87$. Berdasarkan hasil pengolahan data untuk seluruh komponen validitas, menunjukkan bahwa e-modul berbasis contextual teaching and learning pada materi sistem koloid sudah valid dengan nilai $V=0.90$. Kegiatan penilaian ahli dan uji coba satu satu ini menghasilkan prototipe III yang sudah valid. Langkah selanjutnya yaitu melakukan tahap penilaian berupa praktikalitas e-modul dalam kelompok kecil untuk menghasilkan prototipe IV. Praktikalitas emodul dilakukan bersama 15 orang peserta didik dan 3 orang guru kimia. Grafik hasil uji praktikalitas dapat dilihat pada Gambar 4 . 


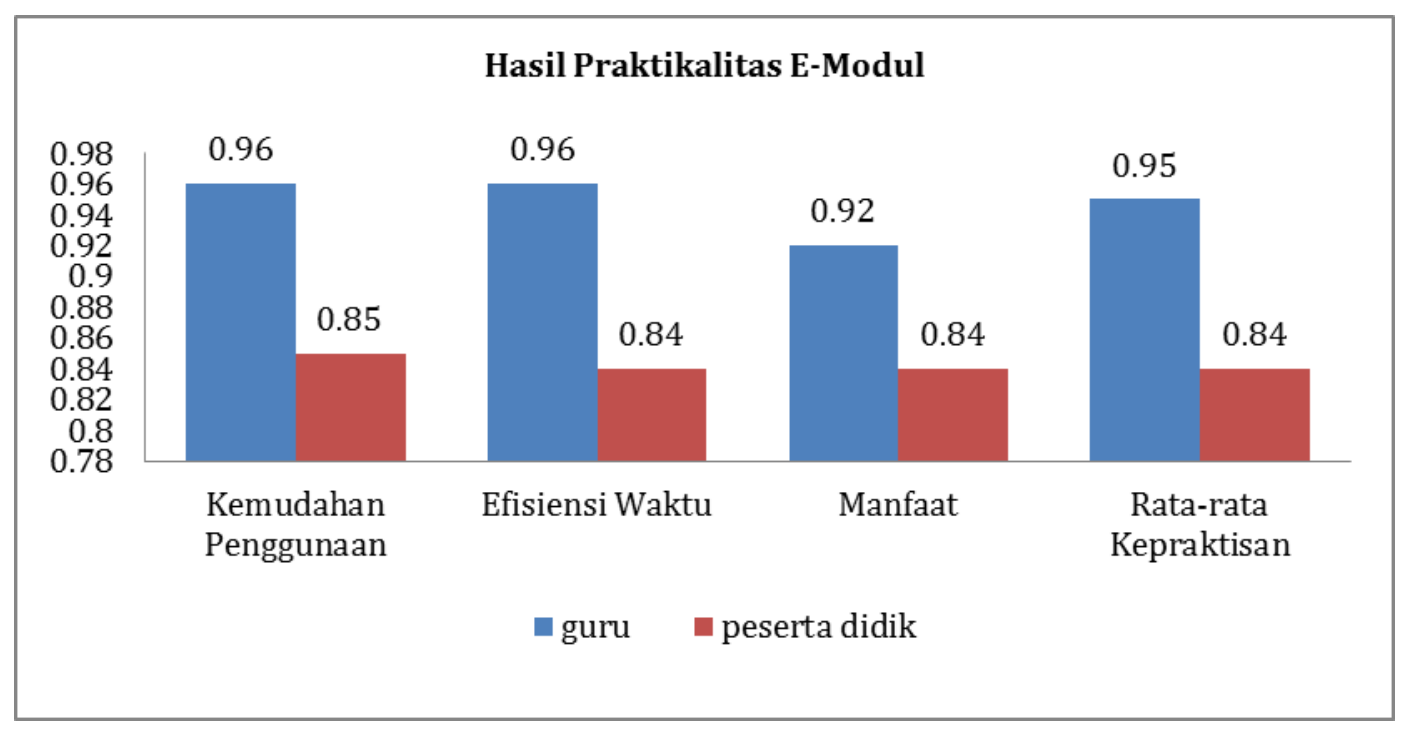

Gambar 4. Grafik nilai praktikalitas e-modul.

Berdasarkan hasil analisis data praktikalitas pada gambar 4, kepraktisan e-modul dinilai dari 3 aspek yaitu kemudahan penggunaan, efisiensi waktu pembelajaran dan manfaat. Aspek kemudahan penggunaan berkaitan dengan penggunaan e-modul dalam proses pembelajaran. Aspek efisiensi waktu berkaitan dengan penggunaan waktu pembelajaran untuk mempelajari e-modul. Sedangkan aspek manfaat berkaitan dengan manfaat yang didapatkan setelah belajar menggunakan e-modul berbasis CTL pada materi sistem koloid. Berdasarkan hasil pengolahan data uji praktikalitas, diperoleh nilai persentase untuk aspek kemudahan penggunaan dari respon guru dan respon peserta didik berturut-turut $96 \%$ dan 85\%. Penilaian aspek kemudahan penggunaan dari respon guru memiliki kategori sangat praktis sedangkan respon dari peserta didik memiliki kategori praktis. Ditinjau dari aspek efisiensi waktu pembelajaran, diperoleh nilai persentase dari respon guru dan peserta didik berturut-turut $96 \%$ dan $84 \%$. Penilaian dari respon guru memiliki kateogi sangat praktis dan respon peserta didik memiliki kategori praktis. Ditinjau dari aspek manfaat e-modul, diperoleh nilai persentase dari respon guru dan peserta didik berturut-turut 95\% dan 84\%. Hasil pengolahan data secara keseluruhan menunjukkan bahwa praktikalitas dari angket respon guru 95\% dengan kategori sangat praktis dan respon peserta didik $84 \%$ dengan kategori praktis. Berdasarkan hasil pengolahan data, komponen penyajian dari e-modul dinyatakan sudah valid dengan nilai $\mathrm{V}=0.92$.

\section{Pembahasan}

Berdasarkan hasil penelitian e-modul yang telah dikembangkan sesuai dengan kurikulum yang berlaku pada saat sekarang yaitu kurikulum 2013 revisi 2018 yang meliputi tuntutan kompetensi dasar (KD) dan indikator pencapaian kompetensi (IPK). Bahan ajar dapat dikatakan valid apabila telah sesuai dengan kurikulum yang ada (Hafsah et al., 2016; N. P. A. Wijayanti et al., 2016). Hal ini dapat dilihat dari beberapa aspek. Pertama, aspek materi e-modul yang telah dikembangkan memiliki kebenaran materi, kesesuaian soal-soal latihan dengan materi serta e-modul dapat meningkatkan pengetahuan siswa. Emodul telah dikembangkan menggunakan bahasa yang komunikatif dan tidak menimbulkan kerancuan. Bahan ajar harus disusun menggunakan kalimat dan bahasa yang jelas dan mudah dibaca (Yerimadesi et al., 2017). Petunjuk dan informasi yang disampaikan dalam e-modul sudah jelas, namun Penilaian kegrafisan adalah penilaian terhadap tampilan dan desain dari e-modulData ini menunjukkan bahwa emodul disajikan dengan baik yaitu e-modul dapat diamati dengan jelas, tata letak, jenis dan ukuran huruf serta secara keseluruhan desain tampilan dinilai bagus dan menarik. Namun terdapat beberapa saran dari validator terhadap tampilan e-modul diantaranya menuliskan kata peta konsep dan menuliskan kelima komponen CTL. Semua saran diterima dan e-modul sudah diperbaiki.

Kedua, aspek kebahasaan kemenarikan, kejelasan dan kesalahan dari e-modul. E-modul memiliki tampilan yang sudah menarik dan tidak terdapat kesalahan yanng fatal. Pemilihan jenis, ukuran huruf, dan penggunaan bahasa mudah dipahami serta tahapan pembelajaran contextual teaching and learning sudah jelas. E-modul dari segi materi, kejelasan bahasa, kejelasan pertanyaan serta tahapan pembelajaran mudah dipahami dan jelas. Sehingga secara keseluruhan, e-modul mudah digunakan dalam pembelajaran. Berdasarkan hasil jawaban peserta didik pada lembar evaluasi menunjukkan hasil yang baik. Hal ini juga menunjukkan bahwa e-modul memiliki pentunjuk penggunaan yang mudah dipahami. Hal ini 
menunjukkan bahwa dengan menggunakan e-modul membuat waktu pembelajaran menjadi lebih efisien dan peserta didik dapat belajar sesuai dengan kecepatannya sendiri. Penggunaan bahan ajar dapat membantu guru dalam menyampaikan materi, sehingga waktu pembelajaran menjadi lebih efisien (Asmiyunda et al., 2018).

E-modul memiliki nilai kategori sangat praktis dari respon guru dan praktis dari respon peserta didik. Hal ini menunjukkan bahwa e-modul yang telah dikembangkan dapat meningkatkan motivasi belajar peserta didik, membantu peserta didik dalam memahami materi pelajaran khususnya materi sistem koloid. E-modul disusun menggunakan komponen pembelajaran contextual teaching and learning meliputi 5 komponen. Pembelajaran kontekstual membuat peserta didik aktif dalam belajar dan mampu meningkatkan hasil belajar (Nanda et al., 2017; Susiloningsih, 2016). Komponen pertama yaitu relating. Relating merupakan kegiatan menghubungkan informasi baru dengan pengetahuan yang sudah diketahui oleh peserta didik dalam kehidupannya. Pembelajaran yang baik dimulai dari pertanyaan dan fenomena yang menarik serta familiar bagi peserta didik bukan dari sesuati yang abstrak atau fenomena di luar pemahaman mereka. Kegiatan menghubungkan dan mengalami merupakan salah satu strategi untuk meningkatkan kemampuan peserta didik untuk belajar menemukan konsep baru, sehingga kegiatan tersebut harus dirancang dan disusun sebaik mungkin (Gerhardt-Szép et al., 2017; Nurhasnah \& Sari, 2020). Berdasarkan hal tersebut e-modul ini valid dan layak digunakan pada proses pembelajaran.

Temuan ini diperkuat deng temuan penelitian sebelumnya yang menyatakan e-modul layak digunakan pada proses pembelajaran (Hamid et al., 2020; Jannah et al., 2021). E-modul juga dapat membantu siswa dalam memahami materi (Groth et al., 2018; Herawati \& Muhtadi, 2018). Emodul berbasis contextual teaching learning dapat meningkatakan literasi sains siswa SMA (Nurhasnah \& Sari, 2020). Walaupun penelitian menunjukkan hasil yang baik, namun dalam pelaksanaannya terdapat beberapa kendala antara lain secara keseluruhan partisipasi peserta didik dalam mengerjakan e-modul sudah baik, namun ada beberapa peserta didik yang kurang fokus dan kurang teliti, jaringan wifi di sekolah bermasalah sehingga peserta didik tidak dapat melakukan pengisian jawaban pada lembar kerja, solusinya peserta didik menjawab pertanyaan pada lembar kerja Microsoft word. Implikasi penelitian ini diharapkan dapat membantu siswa dalam memahami materi system koloin. Sehingga dapat meningkatkan hasil belajar siswa.

\section{SIMPULAN DAN SARAN}

E-modul berbasis contextual teaching and learning pada materi sistem koloid untuk SMA/MA dinyatakan sudah valid dan praktis. Maka peneliti menyarankan agar e-modul ini dapat digunakan oleh guru pada kegiatan pembelajaran.

\section{DAFTAR RUJUKAN}

Antara, \& Aditya, P. (2019). Pengaruh Model Pembelajaran Kontekstual Terhadap Kemampuan Membaca Permulaan Anak. Mimbar Ilmu, 24. https://doi.org/http://dx.doi.org/10.23887/mi.v24i2.21263.

Asmiyunda, A., Guspatni, G., \& Azra, F. (2018). Pengembangan E-Modul Kesetimbangan Kimia Berbasis Pendekatan Saintifik untuk Kelas XI SMA/ MA. Jurnal Eksakta Pendidikan (JEP), 2(2), 155. https://doi.org/10.24036/jep/vol2-iss2/202.

Depdiknas. (2008). Panduan Penyusunan Bahan Ajar. Direktorat Pembinaan SMA.

Dewi, P. yulia A., \& Primayana, K. H. (2019). Effect of Learning Module with Setting Contextual Teaching and Learning to Increase the Understanding of Concepts. International Journal of Education and Learning, 1(1), 19-26. https://doi.org/10.31763/ijele.v1i1.26.

Dewi, W. A. F. (2020). Dampak COVID-19 terhadap Implementasi Pembelajaran Daring di Sekolah Dasar. EDUKATIF : JURNAL ILMU PENDIDIKAN, 2(1), 55-61. https://doi.org/10.31004/edukatif.v2i1.89.

Ernica, S. Y. (2019). Validitas dan praktikalitas e-modul sistem koloid berbasis pendekatan saintifik. Ranah Research, 812-820.

Gerhardt-Szép, S., Dreher, S., Rüttermann, S., \& Weberschock, T. (2017). Konzeption und Implementierung eines neuartigen E-Learning-Moduls mit EbM-Lerninhalten im Fach ZahnerhaltungskundeConception and implementation of a novel E-learning module with EbM learning contents in operative dentistry. Zeitschrift Für Evidenz, Fortbildung Und Qualität Im Gesundheitswesen, 127-128, 72-78. https://doi.org/10.1016/j.zefq.2017.09.001.

Gevi, G. R., \& Andromeda, A. (2019). Pengembangan E-Modul Laju Reaksi Berbasis Inkuiri Terbimbing Terintegrasi Virtual Laboratory Untuk SMA/ MA. Edukimia, 1(1), 53-61. https://doi.org/10.24036/ekj.v1.i1.a8.

Groth, M., Barthe, K. G., Riemer, M., Ernst, M., Herrmann, J., Fiehler, J., \& Buhk, J. H. (2018). Critical Analysis 
of an e-Learning and Interactive Teaching Module with Respect to the Interpretation of Emergency Computed Tomography of the Brain. RoFo Fortschritte Auf Dem Gebiet Der Rontgenstrahlen Und Der Bildgebenden Verfahren, 190(4), 334-340. https://doi.org/10.1055/s-0043-124191.

Hafsah, N. R., Rohendi, D., \& Purnawan, P. (2016). Penerapan Media Pembelajaran Modul Elektronik Untuk Meningkatkan Hasil Belajar Siswa Pada Mata Pelajaran Teknologi Mekanik. Journal of Mechanical Engineering Education, 3(1), 106. https://doi.org/10.17509/jmee.v3i1.3200.

Hamid, M. A., Yuliawati, L., \& Aribowo, D. (2020). Feasibility of electromechanical basic work e-module as a new learning media for vocational students. Journal of Education and Learning (EduLearn), 14(2), 199-211. https://doi.org/10.11591/edulearn.v14i2.15923.

Handini, D., Gusrayani, D., \& Panjaitan, R. L. (2016). Penerapan Model Contextual Teaching And Learning Meningkatkan Hasil Belajar Siswa Kelas IV pada Materi Gaya. Jurnal Pena Ilmiah, 1(1), 451-460. https://doi.org/10.23819/pi.v1i1.2974.

Herawati, N. S., \& Muhtadi, A. (2018). Pengembangan Modul Elektronik (E-Modul) Interaktif Pada Mata Pelajaran Kimia kelas XI SMA. Jurnal Inovasi Teknologi Pendidikan, 5(2), 180-191. https://doi.org/10.21831/jitp.v5i2.15424.

Islamiati, N., Rahmawati, R., \& Haris, M. (2020). Pengaruh Model Pembelajaran Berbasis Masalah Terhadap Hasil Belajar Kimia Siswa Kelas X MS SMAN 1 Kediri Pada Materi Reaksi Reduksi Dan Oksidasi. Chemistry Education Practice, 3(2), 112. https://doi.org/10.29303/cep.v3i2.2044.

Jannah et al. (2021). Efektivitas Penggunaan E-Modul Terhadap Hasil Belajar Kognitif Pada Materi Sistem Pencernaan Manusia di Madrasah Tsanawiyah. Jurnal Basicedu, 5(2), 1060-1066. https://doi.org/10.31004/basicedu.v5i3.952.

Kodir, A., Hartono, D. M., Haeruman, H., \& Mansur, I. (2017). Integrated post mining landscape for sustainable land use: A case study in South Sumatera, Indonesia. Sustainable Environment Research, 27(4), 203-213. https://doi.org/10.1016/j.serj.2017.03.003.

Kulagina, K., Leksashova, A., Bolsunovskayaa, M., \& Shirokovaa, S. (2021). Development of a Human Flow Generation Module for Testing Machine Learning Algorithms. Transportation Research Procedia, 54, 783-792. https://doi.org/10.1016/j.trpro.2021.02.134.

Media, P., Berbasis, O., Classroom, G., Pemahaman, M., Pada, S., Pelajaran, M., Di, P. A. I., Khamim, M., Islam, P. A., Tarbiyah, F., \& Ilmu, D. A. N. (2021). Penerapan media online berbasis google classroom dalam meningkatkan pemahaman siswa pada mata pelajaran pai di masa pandemi covid-19 di sman 2 ponorogo.

Miranda, J., Navarrete, C., Noguez, J., \& Espinosa, J.-M. M.-. (2021). The core components of education 4.0 in higher education: Three case studies in engineering education. Computers \& Electrical Engineering, 93, 107278. https://doi.org/10.1016/j.compeleceng.2021.107278.

Nanda, K. K., Tegeh, I. M., \& Sudarma, I. K. (2017). Pengembangan video pembelajaran berbasis pendekatan kontekstual kelas V di SD Negeri 1 Baktiseraga. Jurnal Edutech Universitas Pendidikan Ganesha, 5(1), 88-99. https://ejournal.undiksha.ac.id/index.php/JEU/article/view/20627.

Nugrahaeni, A., Redhana, I. W., \& Kartawan, I. M. A. (2017). Penerapan Model Pembelajaran Discovery Learning untuk Meningkatkan Kemampuan Berpikir Kritis dan Hasil Belajar Kimia. Jurnal Pendidikan Kimia Indonesia, 1(1), 23-29. https: //doi.org/10.23887/jpk.v1i1.12808.

Nurhasnah, \& Sari, L. A. (2020). E-Modul Fisika Berbasis Contextual Teaching And Learning Menggunakan Aplikasi Kvisoft Flipbook Maker Untuk Meningkatkan Literasi Sains Peserta Didik SMA/MA Kelas XI. NATURAL SCIENCE: Jurnal Penelitian Bidang IPA Dan Pendidikan IPA, 6(1), 29-40.

Nurkolis, N., \& Muhdi, M. (2020). Keefektivan Kebijakan E-Learning berbasis Sosial Media pada PAUD di Masa Pandemi Covid-19. Jurnal Obsesi : Jurnal Pendidikan Anak Usia Dini, 5(1), 212. https://doi.org/10.31004/obsesi.v5i1.535.

Plomp, T. (2007). An Introduction to Educational Design Research. Netherlans institute.

Purwanto, N. (2009). Prinsip-Prinsip dan Teknik Evaluasi Pengajaran. Remaja Rosdakarya.

Putria, H. (2020). Analisis Proses Pembelajaran Dalam Jaringan (DARING) Masa Pandemi COVID-19 pada Guru Sekolah Dasar. Jurnal BASICEDU, 4(4), 861-872. https://doi.org/10.31004/basicedu.v4i4.460.

Rahmawati, T. R. (2018). Penerapan Model Pembelajaran CTL untuk Meningkatkan Hasil Belajar Siswa Sekolah Dasar Pada Mata Pelajaran IPA. Jurnal Imiah Pendidikan Dan Pembelajaran, 2(1), 12-20. https://doi.org/10.23887/jipp.v2i1.13765.

Ranny, R. (2019). Pengembangan E-Modul Sistem Koloid Berbasis Discovery Learning untuk SMA/MA. Journal of RESIDU, 3(19), 160-166.

Ratnasari, S. F., \& Saefudin, A. A. (2018). Efektivitas Pendekatan Contextual Teaching And Learning (CTL) Ditinjau Dari Kemampuan Komunikasi Matematika Siswa. Jurnal Matematika Dan Pembelajaran, 6(1), 119-127. https://doi.org/10.24252/mapan.2018v6n1a11.

Retnawati. (2016). Analisis Kuantitatif Instrumen Penelitian. Parama. 
Riduwan, \& Sunarto. (2007). Pengantar Statistika: Untuk Penelitian Pendidikan, Sosial, Ekonomi, dan Bisnis. Alfabeta.

Rochmad. (2012). Desain Model Pengembangan Perangkat Pembelajaran Matematika. Jurnal Kreano, 3(1).

Sailer, M., Schultz-Pernice, F., \& Fischer, F. (2021). Contextual facilitators for learning activities involving technology in higher education: The C b -model. Computers in Human Behavior, 121(October 2020), 106794. https://doi.org/10.1016/j.chb.2021.106794.

Sedana, Suwatra, \& Suranata. (2013). Pengaruh Model CTL Bermuatan Tri Hita Karana Terhadap Hasil Belajar IPA Siswa Kelas IV di Gugus I Kecamatan Buleleng. MIimbar PGSD Undiksha, 1(1). https://doi.org/10.23887/jjpgsd.v1i1.839.

Setiawan, A. R. (2020). Lembar Kegiatan Literasi Saintifik untuk Pembelajaran Jarak Jauh Topik Penyakit Coronavirus 2019 (COVID-19). EDUKATIF: JURNAL ILMU PENDIDIKAN, 2(1), 28-37. https://doi.org/10.31004/edukatif.v2i1.80.

Solikin, I. (2018). Implementasi E-Modul pada Program Studi Manajemen Informatika Universitas Bina Darma Berbasis Web Mobile. Jurnal RESTI (Rekayasa Sistem Dan Teknologi Informasi), 2(2), 492497. https://doi.org/10.29207/resti.v2i2.393.

Sudarmin, S., \& Samini, S. (2016). Efektivitas penggunaan modul terintegrasi etnosains dalam pembelajaran berbasis masalah untuk meningkatkan literasi sains siswa. Unnes Science Education Journal, 4(3). https://doi.org/10.15294/USEJ.V4I3.8860.

Sulfemi, W. B. (2019). Model Pembelajaran Contextual Teaching And Learning (CTL) Berbantu Media Miniatur Lingkungan Untuk Meningkatkan Hasil Belajar IPS. Edunomic Jurnal Pendidikan Ekonomi, 7(2), 73. https://doi.org/10.33603/ejpe.v7i2.1970.

Susiloningsih, W. (2016). Model Pembelajaran CTL (Contextual Teaching and Learning) dalam Meningkatkan Hasil Belajar Mahasiswa PGSD Pada MataKuliah Konsep IPS Dasar. PEDAGOGIA: Jurnal Pendidikan, 5(1), 57. https://doi.org/10.21070/pedagogia.v5i1.89.

Udy Nugroho, A. Y., Hanatan, A., . S., \& . S. (2019). Learning Module for Elementary School Students Using Learning Model Based on LCM Theory. International Journal of Educational Research Review, 4(1), 44-49. https://doi.org/10.24331/ijere.472797.

Wijayanti, N. P. A., Damayanthi, L. P. E., Sunarya, I. M. G., \& Putrama, I. M. (2016). Pengembangan E-Modul Berbasis Project Based Learning Pada Mata Pelajaran Simulasi Digital Untuk Siswa Kelas X Studi Kasus di SMK Negeri 2 Singaraja. Jurnal Pendidikan Teknologi Dan Kejuruan, 13(2), 184-197. https://doi.org/10.23887/jptk-undiksha.v13i2.8526.

Wijayanti, R. M., \& Fauziah, P. Y. (2020). Perspektif dan Peran Orangtua dalam Program PJJ Masa Pandemi Covid-19 di PAUD. Jurnal Obsesi: Jurnal Pendidikan Anak Usia Dini, 5(2), 1304-1312. https://doi.org/10.31004/obsesi.v5i2.768.

Wildani, A., Budiyono, A., \& Zaitun, Z. (2021). Pengaruh Model Contextual Teaching and Learning (CTL) Berbantuan Media Ular Tangga Terhadap Penguasaan Konsep Fisika Siswa. Jurnal Pendidikan Fisika Dan Teknologi, 7(2), 96-103. https://doi.org/10.29303/jpft.v7i2.2864.

Yerimadesi, Y., Bayharti, B., Handayani, F., \& Legi, W. F. (2017). Pengembangan Modul Kesetimbangan Kimia Berbasis Pendekatan Saintifik Untuk Kelas XI SMA / MA. Sainstek : Jurnal Sains Dan Teknologi, 8(1), 85. https://doi.org/10.31958/js.v8i1.444.

Yulkifli, Yanto, E., Agustia, R., Ihsan, I., \& Yohandri. (2020). Development Of Electronic Physics Module For Class XI High School Semester 2 Using Model Inquiry Based Learning Integrated Approach Contextual Teaching And Learning. Journal of Research \& Method in Education, 10(2), 41-52. https://doi.org/10.9790/7388-1002014152.

Yusnindar, E. \&. (2015). Pengembangan Modul Berbasis Pendekatan Kontekstual Materi Sistem Koloid untuk Mahasiswa Kimia Dasar II Prodi Pendidikan Kimia. Journal of The Inonesian Society of Intregated Chemistry, 7(1), 1-8. https://doi.org/10.22437/jisic.v7i1.4831.

Zulaiha, S. (2016). Pendekatan Contextual Teaching and Learning dan Implementasinya dalam Rencana Pembelajaran PAI MI. BELAJEA: Jurnal Pendidikan Islam, Vol 1(1), 42-60. https://doi.org/10.29240/bjpi.v1i1.84.

Zulkarnain, A., Kadaritna, N., \& Tania, L. (2015). Pengembangan E-Modul Teori Atom Mekanika Kuantumberbasis Web Dengan Pendekatan Saintifik. Jurnal Pendidikan Dan Pembelajaran Kimia, 4(1), 222-235. http://jurnal.fkip.unila.ac.id/index.php/JPK/article/view/8712. 